\title{
SOCIETY AGING PROBLEMS AND THEIR SOLUTIONS IN LATVIA, LITHUANIA AND POLAND
}

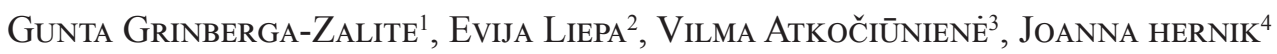 \\ Latvia University of Agriculture (Latvia), Latvia Business College (Latvia), \\ Aleksandras Stulginskis University (Lithuania), \\ West Pomeranian University of Technology (Poland)
}

\begin{abstract}
The European Union data surveys give evidence of the growing trend of population ageing in the Member States. The aim of the study was to analyse the social structure of population in Latvia, Lithuania and Poland in comparison with the average population in the EU-27 and present recommendations for policy makers for further improvement of the social policy development in these countries. The authors used monographic method to study theoretical aspects of society aging and welfare and statistical data analysis of secondary data aggregated by Eurostat reports, Eurobarometer survey and databases of national institutions. The analysis of the society aging indicators in Latvia, Lithuania and Poland clearly shows that the policy makers of these countries so far have been mainly focusing on unpopular measures - either increasing taxes or raising the retirement age, which have caused citizens' dissatisfaction with the existing social policy that does not provide any hopes for the existing and becoming pensioners to approximate to successful aging. The authors consider that the national institutions responsible for society's welfare issues should further encourage socially innovative solutions by finding unusual ideas for obtaining multidimensional support, including the assistance provided by policy-makers and involving local agents to enhance inclusion of the aged population in the labour market, especially in creating jobs for themselves, being able to retain employment as temporary workers or being encouraged to work in other professions. KEYWORDS: society ageing, retirement, quality of life, successful ageing, social structure of society.
\end{abstract}

JEL CODE: I31, I38

1 Gunta Grinberga - dr. oec., associate professor, Latvia University of Agriculture, Faculty of Economics and Social Development. Scientific interests: regional economic, social innovation

E-mail: gunta.grinberga@1lu.lv

Tel. +371 29463545

2 Elvija Liepa - dr. math., associate professor, Latvian Business College. Scientific interests: econometrics, statistics

E-mail: eliepa2@gmail.com

Tel. +37129557195

3 Vilma Atkočiūnienè - dr., professor Aleksandras Stulginskis University. Scientific interests: rural communities development, rural regional development, development of rural social infrastructure, local marketing, social partnership

E-mail: vilma.atkociuniene@gmail.com

Tel. +3707752214

4 Joanna Hernik - dr., professor West Pomeranian University of Technology Scientific interests: marketing, corporate social responsibility, communication

E-mail: zut@zut.edu.pl

Tel. +914494111 


\section{Introduction}

In the changing environment of nowadays, when a variety of changes both economic and social take place, the society becomes vulnerable as these changes have an impact on each individual's life. The society's ability to comply with the changes and challenges of life are determined by different factors that are commonly referred to as "quality of life", "welfare", "social role" etc. In the public space, discussions about the topicality of society aging have been lately often initiated, which was also evidenced by the proclamation of the European year 2012 as a year of "active aging" in Europe (Pavulite, 2015).

According to the latest demographic and economy growth indicators of the EU, the economic development of the countries is closely related with the national policy and support measures aimed at balancing the interests of the young and the aging generation. However, not less important factor is the attitude and willingness of the aging population itself to involve actively in improving of their quality of life ${ }^{5}$.

The aim of the present study is to analyse social structure of population in Latvia, Lithuania and Poland in comparison with the average population in the EU-27 and present recommendations for policy makers for further improvement of the social policy development in these countries. The tasks of the research are: 1) to characterize the theoretical aspects of society aging; 2 ) to analyse the population age dynamic and labour resource load in Latvia, Lithuania and Poland in comparison with the EU-27; 3) present recommendations for policy makers for further improvement of the social policy development in these countries.

The authors have chosen to study the aging problems in Latvia, Lithuania and Poland, because Latvia and Lithuania are the EU countries that today more than other EU countries feel the consequences of the 2007-2010 global financial crisis resulting in serious loss of their young working populations that in desperation have left the countries forever to find jobs in the UK, Ireland and Germany. Whereas Poland, which is the closest neighbouring country, has found a better policy how to retain its young and working population, thus has survived this period much easier and, therefore, is interesting for the comparison. In scope of the paper development, the following research methods were applied: monographic method; analysis and synthesis; induction and deduction; statistical data analysis and graphic method. For the secondary data analysis, the authors used Eurostat and Eurobarometer databases; the publications of the European Commission documents, various Internet sources as well as scientific publications and sources available in EBSCO database.

\section{Theoretical aspects of society aging}

One of the most common and demonstrative frameworks of aging theories has been developed by Giddens (Giddens, 2006) dividing aging theories according to three periods.

First period theories were popular in the 50-60s of the $20^{\text {th }}$ century. In these theories, functionalism dominates, thus individual's integration in society is connected with implementing particular roles. Consequently, alongside with person's aging, the abilities of this person to fulfil these functions reduce and the needs for the change in social roles arise. Second period theories prevailed in the societies during the $70 \mathrm{~s}$ of the $20^{\text {th }}$ century. The most common of these theories is known as aging stratification theory and is focused on the social structure, e.g. interaction between retirement and overall society's aging. In scope of this theory, aging is viewed as a particular stage of life, which is influenced by historical, economic, social and environmental factors that have been developing since the moment of person's birth until death. Third period theories emphasize that the existing economic and political systems affect elderly people by reducing their employment opportunities providing them insufficient pensions and such institutional environment

5 The paper was elaborated in scope of the project "Involvement of the Society in Social Innovation for Providing Sustainable Development of Latvia" supported by the National Research Program 5.2. "Economic Transformation, Smart Growth, Governance and Legal Framework for the State and Society for Sustainable Development - a New Approach to the Creation of a Sustainable Learning Community (EKOSOC-LV)". 
that makes elderly people even more helpless and dependent. Also in scope of this theory, the conditions of elderly people are regarded only as closely connected with the overall society (Rungule, 2012).

However, nowadays society aging problem is more often connected with such concepts as "quality of life" and "successful aging", thus focusing on internal and external changes that individual society member might be exposed to in his/her daily life. According to the definitions formulated by the organizations World Health Organization and Health-Related Quality of Life, the concept "quality of life" is a broad multidimensional concept that usually includes subjective evaluations of both positive and negative aspects of life. Although health is one of the important domains of overall quality of life, there are other domains as well, for instance, jobs and socializing opportunities.

The concept "successful ageing" refers to physical, mental and social well-being in older age. The concept of successful aging can be traced back to the 1950s, and was popularized in the 1980s. It reflects changing view on aging in Western countries, where a stigma associated with old age has led to considering older people as a burden on society. Consequently, in the past most of the scientists have been focusing on negative aspects of aging or preventing the decline of youth (Rowe, Kahn, 1997; Fries 2002). V. Liesionis, M. Račkauskas (2012) analyzed the effectiveness of government expenditure allocation according to the opinion of different authors about productive expenditure and its influence to economic growth. They found relation between productive expenditure and people ageing. This relation showed that ageing affects productive expenditures growth negatively.

In our daily life, each seemingly modest detail or incompleteness of the aging process is able to lead to significant consequences for the entire country's economy. British researcher Tejvan Pettinger (2013) from Oxford University emphasizes the reasons why exactly it is necessary for every member of society to involve actively in solving society aging problems.

- The load factor increase. At a fixed retirement age and increase of life expectancy, the number of pensioners will increase, while the number of workers and taxpayers will decrease. There is concern that this will result in an increase in tax rates, which will be imposed to labour force.

- Increase in government spending on health care and the pension fund, but the fall in tax revenue, because pensioners' tax rates are lower. Especially important it is in the countries with the current sovereign debt problems and disorderly pension fund systems.

- Workers have to pay higher taxes. This may create a barrier to business development and investment opportunities, as well as productivity and growth problems.

- Labour shortages. Aging can cause labour shortages resulting in wage increases, which would cause wage inflation. Alternatively, employers can use flexible work schedule, attracting a greater number of employees implementing aged population employment policy.

- Changes in the economic sector. Increase in the number of pensioners will result in an increase in goods and services related to the elderly (such as retirement homes).

- Capital reduction. This is due to large savings to the pension fund. An increase in the contribution to the pension fund reduces productivity-enhancing investments, resulting in lower economic growth rate (Pettinger, 2013).

The Lithuanians scientists S. Lengvinienè, A. Rutkienè, I. Tandzegolskienè (2014) emphasized that it is necessary to discuss in society on topic of active ageing. It is important to understand in generally, that senior people can and wish to work and discuss on this issue with social partners, training providers and also with employees. This is also connected with willingness and ambition to remain in the labour market and feel safe, so the question of non-discrimination, flexible work schedule, and possibility of improvement is very significant for senior people. Promotion of volunteering work in groups of senior people could be in agenda too. 
2. Population age dynamic and labour resource load in Latvia, Lithuania and Poland

Based on the Eurostat data, the authors aggregated the proportion of total population aged 50-64 in Latvia, Lithuania, Poland and the EU-27. In Figure 1, it is shown that during the last three years in all the three analysed countries the proportion of elderly people has been larger than in the EU-27 on average. However, despite the fact that among the analysed three countries Poland has been in leading position with a rapid increase of its population aged 50-64, which has been constantly increasing until 2012. However, since 2013 Poland has been the only country among the analysed countries, in which there can be seen positive tendencies.

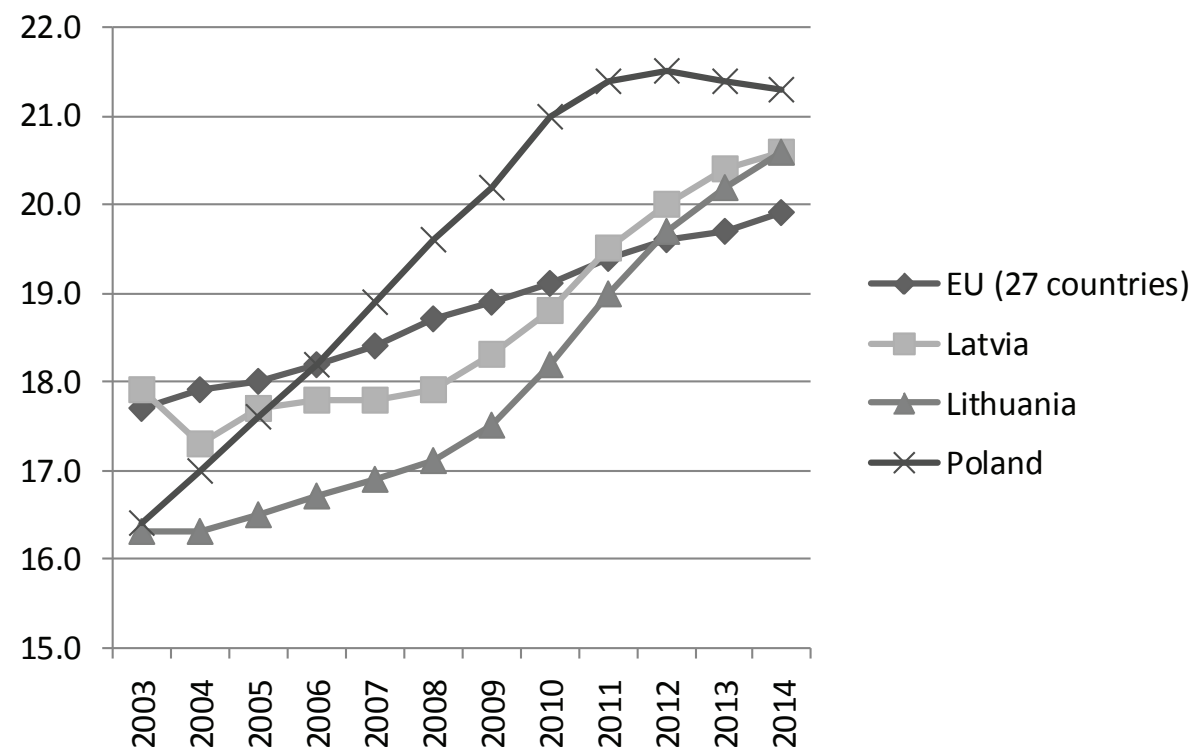

Figure 1. Proportion of total population aged 50-64 in Latvia, Lithuania, Poland and the EU-27, \%

Source: Eurostat, Population by Age Group, 2014

Based on the World Fact Book data, the authors aggregated the information about the population at retirement age dependency ratio in 2014 in Latvia, Lithuania and Poland. The values of this coefficient in all the three countries although slightly differ (in Latvia - $29.35 \%$; Lithuania $-24.46 \%$; Poland $-21.31 \%$ ), clearly show that the policy makers of these countries have to take unpopular measures - either increase taxes or raise the retirement age.

Since 1973, the European Commission has been monitoring the public opinion in the Member States, thus helping the preparation of decision-making and the evaluation of its work. These surveys and studies address major topics concerning European citizens. The Eurobarometer Survey No 57 was devoted to identification of the most important issues that the EU citizens are facing at the moment. In the Table 1, the authors aggregated data for 2011 and 2014 available in the EU Eurobarometer Survey No 57 to find out if the situation in the three analysed countries differs and if it complies with the overall mood in the European Union as a whole. The survey data reveal the situation that although people have overcome the negative effects of the global financial crisis of 2007-2010 and their concerns about the rising prices have declined, in all the three analysed countries and in the EU as a whole, the health and social security issues are present among the top three citizens' concerns in 2014. Latvians and poles are most upset about this aspect, accordingly - $16 \%$ and $13 \%$ of the respondents, which leads to the conclusion that the existing social policy needs to be improved in these countries. Latvia and Poland indicate one more similarity - in both countries the third most urgent issue that upsets the citizens is pensions. This could be explained by the situation, that according to Eurostat data, 
Latvia and Poland are among those countries with the largest proportion of population aged 50-64. According to the survey data, seems that Lithuania citizens are seriously worried about the taxation system, which both in 2011 and 2014 has been claimed as one of the most worrying issues. The overall situation in the European Union gives evidence of the citizens' dissatisfaction with the existing social policy, which does not provide any hopes for the existing and becoming pensioners to move closer to so-called "successful aging".

Table 1. The public opinion about issues that upset the citizens in Latvia, Lithuania and Poland

\begin{tabular}{|c|c|c|c|}
\hline Country & Year & Top three issues that upset the citizens & $\%$ \\
\hline \multirow{6}{*}{ Latvia } & \multirow{3}{*}{2011} & Rising prices & 28 \\
\hline & & Economic situation in the country & 17 \\
\hline & & Unemployment & 14 \\
\hline & \multirow{3}{*}{2014} & Rising prices & 20 \\
\hline & & Health and social security & 16 \\
\hline & & Pensions & 10 \\
\hline \multirow{6}{*}{ Lithuania } & \multirow{3}{*}{2011} & Rising prices & 35 \\
\hline & & Economic situation in the country & 12 \\
\hline & & Taxation & 12 \\
\hline & \multirow{3}{*}{2014} & Rising prices & 30 \\
\hline & & Taxation & 18 \\
\hline & & Health and social security & 9 \\
\hline \multirow{6}{*}{ Poland } & \multirow{3}{*}{2011} & Rising prices & 32 \\
\hline & & Health and social security & 16 \\
\hline & & Unemployment & 13 \\
\hline & \multirow{3}{*}{2014} & Rising prices & 18 \\
\hline & & Health and social security & 13 \\
\hline & & Pensions & 12 \\
\hline \multirow{6}{*}{ EU } & \multirow{3}{*}{2011} & Rising prices & 26 \\
\hline & & Economic situation in the country & 12 \\
\hline & & Unemployment & 11 \\
\hline & \multirow{3}{*}{2014} & Rising prices & 17 \\
\hline & & Financial situation in the country/Unemployment & 11 \\
\hline & & Health and social security & 9 \\
\hline
\end{tabular}

Source: authors' created according to the EU Eurobarometer Survey No.57 data for 2011 and 2014

In the further part of the research, the authors assessed the possibilities of aged population to find jobs and studied the unemployed population by age groups. Due to the present article volume limitations, the authors assessed the situation only in one of the three countries - Latvia. This country was chosen because it indicated the largest population at retirement age dependency ratio among the three countries (29.35\%). According to the Latvian State Employment Agency latest data on the situation in April 2015, in Latvia the largest proportion of the unemployed population was constituted by the population aged 50 years and over $-37.2 \%$, the aggregated data also show that the same group of population is exposed to the long-term unemployed $-31.7 \%$. Compared with the corresponding period one year ago, the unemployed population aged 50 years and over has increased by 0.5 percentage points (State Employment Agency of the Republic of Latvia, 2015). This situation clearly shows that the current social policy approach has not been able to find efficient solutions how to balance the younger and elderly generations' coexistence in the labour market, thus constantly lagging behind other EU countries and reducing populations' quality of life. The authors consider that one of the explanations for the high level unemployment among Latvian population aged 50 years and over could be so-called "cult of youth" that lately in more open manner prevails in Latvian business environment. In many industries, e.g. retail trade of cosmetics and clothing, hotel and hospitality etc., official recruitment policies of the companies are formulated only on paper, but in reality, completely different principles are applied in the recruitment of the staff. 


\section{Potential solutions to the society aging problems}

As it was already described by the secondary data analysis, the current situation in the three analysed countries show very little chances of balancing the needs of the aging population with the abilities of the younger generation, which, according to the previously practiced policy, usually result in mainly two unpopular directions of activities - either raising the age of retirement, or increasing of the taxes. However, societies' pro-active attitude to participate in the decision making process and change their behaviour models are those instruments that give a hope to change for good. Scientists from various countries have shown that self-organization of society and targeted involvement in socially significant initiatives are an essential prerequisite for harmonization of interests of various members of society (Barnes, 2006; Yaojun, Marsh, 2008; Petrova, Tarrow, 2007; Habermas, 1995; Kruzmetra, Rivza, 2014; Grinberga-Zalite, Oganisjana, Surikova, 2015).

Kudins (2012) emphasizes that in order to achieve socially desirable outcomes, people should be able to organize themselves, to face the challenges, identify their needs and priorities and try to satisfy them by (1) self-organisation in groups; (2) local resource mobilization, and (3) by attracting other resources. Yet, according to the results of research conducted in various countries, not every community is able to meet these challenges. The most common reasons why the best intentions of community's initiatives do not reach their goals are lack of education, experience and communication skills and incapability to consolidate different target groups for actions that could improve the lives of each group of individuals and communities as a whole. In recent years, in the world there is a growing interest in social innovation, enhanced by a number of successful implementations of social innovation, e.g. shopping cooperatives, microcredit groups and even such huge projects as Open University and Wikipedia for their nature can be regarded as social innovations, which have found their expression in practical life. All these above examples are united by the fact that these ideas have in their early stage been focused directly on improving the population's quality of life (Mulgan et al., 2006). The authors consider that in addition to the already known activities focused on reducing of social exclusion of people with specific care needs, invalids, foreigners, former prisoners etc., a special attention should be paid to reduce aging people's discrimination at workplaces. In this respect, special social campaigns should be organized to change society's attitude and persuade employers that often elderly people are more experienced and have higher motivation to work than their younger colleagues. Such approach also complies with corporative social responsibility principles, by which companies are able to show solidarity to the aged staff and thus demonstrate to the society that this company not only respects and rewards its elderly staff, but also reduces the number of unemployment among people before retirement age and therefore decreases government spending. Another aspect that is important in authors' view is the need of providing socializing opportunities for aged people. This approach requires enhancing aging population's willingness and abilities to retain their competitiveness in their profession or integrate in other profession to remain employed. Often it is just necessary to reassure them and increase their commitment to remain active in the labour market despite their aging side effects. To attract society's attention, social marketing campaigns should be organized at the national level, thus inviting people to actively search for socially innovative solutions both among aging society and employers. The activities, events and publications available at the European Commission website also give evidence that there is a strong intention to provide support and contribute to the creation of a favourable environment for the development of social business in Europe, and of the social economy at large (The European Commission, 2015).

\section{Conclusions}

Nowadays, every member of society is exposed to unfavourable consequences caused by society aging, such as increase in taxes and retirement age, unfavourable changes in economic sectors, and capital reduction. During 2012-2014, in all the three analysed countries the proportion of elderly people has been larger than in the EU-27 on average. However, despite the fact that among the analysed three countries Poland has 
been in leading position with rapid increase of its population aged 50-64, which has been constantly increasing until 2012, since 2013 Poland is the only country among the analysed countries, in which there can be seen positive tendencies. In 2014, the population at retirement age dependency ratio in Latvia was $29.35 \%$, in Lithuania $-24.46 \%$ and in Poland $-21.31 \%$, which clearly shows that the policy makers of these countries have to take unpopular measures - either increase taxes or raise the retirement age.

The Eurobarometer No.57 survey data revealed the situation that although people have overcome the negative effects of the global financial crisis of 2007-2010 and their concerns about the rising prices have declined, in all the three analysed countries and in the EU as a whole, the health and social security issues are present among the top three citizens' concerns in 2014. Latvians and poles are most upset about this aspect, accordingly $16 \%$ and $13 \%$. Latvia and Poland indicate one more similarity - in both countries the third most urgent issue that upsets the citizens is pensions. Whereas Lithuanians are seriously worried about the taxation system, which both in 2011 and 2014 was claimed as one of the most worrying issues. The overall situation in the European Union gives evidence of the citizens' dissatisfaction with the existing social policy, which does not provide any solutions for the existing and becoming pensioners to move closer to successful aging level.

According to the Latvian State Employment Agency data of April 2015, in Latvia the largest proportion of the unemployed population was constituted by the population aged 50 years and over $-37.2 \%$. The aggregated data also show that the same group of population is exposed to the long-term unemployed $-31.7 \%$. One of the explanations for the high level unemployment among this population group could be "cult of youth" that lately dominates in Latvian business environment.

Proposals

In order to achieve socially desirable outcomes, people should be able to organize themselves, to face the challenges, identify their needs and priorities and try to satisfy them. Therefore, the authors consider that the national institutions responsible for society welfare issues should further pay a special attention to reducing aging people's discrimination at workplaces. In this respect, special social campaigns should be organized to change society's attitude and persuade employers that often elderly people are more experienced and have higher motivation to work than their younger colleagues. Such approach could also motivate employers to emphasize this aspect in their corporative social responsibility programmes, by which companies are able to show solidarity to the aged staff and demonstrate to the society that this company not only respects and rewards its elderly staff, but also reduces the number of unemployment among people before retirement age and thus decreases government spending.

It is necessary to provide socializing opportunities for aged people. This approach requires enhancing their willingness and abilities to retain their competitiveness in their profession or integrate in other profession to remain employed. Often it is just necessary to reassure them and increase their commitment to remain active in the labour market despite their aging side effects. To attract society's attention, social marketing campaigns should be organized at the national level, thus inviting people to actively search for socially innovative solutions both among aging society and employers.

The ministries responsible for national economy and social welfare development should activate at all their institutional levels the need for social innovation creation. Social innovations should be encouraged by finding unusual ideas for obtaining multidimensional support, including the assistance provided by policymakers and involving local agents to enhance inclusion of the aged population in the labour market, especially in creating jobs for themselves, being able to retain employment as temporary workers or being encouraged to work in other professions. 


\section{References}

Barnes, H. S. (2006). The Changing Political Participation of Post-Communist Citizens. International Journal of Sociology, Vol. 36, Issue 2, p. 76-98.

Centre for the Disease Control and Prevention. What is Quality of Life? [online]. Available: http://www.cdc.gov/hrqol/ concept.htm [viewed: 03.07.2015].

European Commission Eurobarometer. Public Opinion in the European Union. (2014). Survey No. 57 [online]. Available: http://ec.europa.eu/public opinion/cf/step3.cfm?keyID=3804\&nationID=20 [viewed: 03.07.2015].

Fries, J. F. (2002). "Reducing Disability in Older Age”. JAMA, Vol. 288 (24), p. 3164-6.

Grinberga-Zalite, G., Oganisjana, K., Surikova, S. (2015). The Study of Social Innovation Theoretical Framework for Enhancing of Rural Development and Agriculture in Latvia. Economic Science for Rural Development 2015. Proceedings of the International Scientific Conference - 2015, April 23-24, Latvia University if Agriculture, Faculty of Economic and Social Development, Jelgava, Vol. 40, p. 205-215.

Habermas, J. (1995). Moral Consciousness and Communicative Action: Studies in Contemporary German Social Thought. Cambridge: Polity Press, 225 p.

Kruzmetra, M., Rivza, B. (1998). Pagasti un rajoni savas attistibas programmas. Latvijas Vestnesis, gada 28, februaris un 6. marts. [Civil Parishes and Districts in Their Development Programmes. Latvijas Vestnesis / Latvia Messenger, 28 February and 6 March 1998.]

Kudins, V. (2012). Jaunas vesmas vietejas attistibas jautajumu risinasana. Latvijas lauku forums, 3/2012. E-izdevums. [New Trends in Dealing with the Local Development Issues. Latvian Rural Forum, 3/2012. E-Edition.] [viewed: 03.07.2015] Available: http://www.llf.partneribas.lv/resource/1356701708_3_e-izdevums.pdf.

Lengvinienè, S., Rutkienė, A., Tandzegolskienė, I. (2014). Vyresnio amžiaus asmenų išlikimo darbo rinkoje teoriniai aspektai [The Theoretical Aspects of Senior People Survival in the Labour Market]. Vocational Education: Research and Reality, No. 25, p. 128-137.

Liesionis, V., Račkauskas, M. (2012). Produktyvios valstybės išlaidos ir jų poveikis ekonomikos augimui [Productive Government Expenditure and its Influence to the Economic Growth]. Applied Economics: Systematic Research, 2012.6/2, p. 73-86.

Mulgan, G., Tucker, S., Ali, R., Sanders, B. (2006). Social Innovation: What it is, Why it Matters and How it can be Accelerated. Working Paper. London: The Young Foundation, The Basingstoke Press, p. 27.

Pavulite, K. (2015). Opportunities of Social Marketing for Solving Society Ageing Problems in Latvia. Master's thesis. Latvia University of Agriculture, Jelgava, 128 p.

Petrova, T., Tarrow, S. (2007). Transactional and Participatory Activism in the Emerging European Polity: The Puzzle of East-Central Europe. Comparative Political Studies, Vol. 40, Issue 1, p. 74-94.

Pettinger, T. (2013). The Impact of an Ageing Population on the Economy [online]. Economics Help. Available: http:// www.economicshelp.org/blog/8950/society/impact-ageing-population-economy/ [viewed 03.07.2015].

Population by Age Group. Eurostat [online]. Available: http://ec.europa.eu/eurostat/tgm/table.do?tab=table\&init=1\&la nguage $=$ en\&pcode $=$ tps00010\&plugin $=1$ [viewed 02.07.2015].

Rowe, J. W., Kahn, R. L. (1997). Successful Aging. The Gerontologist, Vol. 37 (4), p. 433-440.

Rungule, R., Koroleva, I., Mierina, I., Trapeznikova, I., Karklina, I., Trapenciere, I., Aleksandrovs, A. (2012). Sabiedribas novecosana: sociala aizsardziba, nevienlidziba un darba tirgus riski [Society Aging: Social Protection, Inequality and Risks in the Labour market]. Rezekne: Latgales druka, Vol. 12.-16, 38, 40 p.

State Employment Agency of the Republic of Latvia. Report on Unemployment Situation in the Country. April, 2015 [online]. Available: http:/www.nva.gov.lv/docs/28_555dcfb0f0d223.91597714.pdf [viewed 03.07.2015].

The European Commission. Single Market. Social Entrepreneurship [online]. Available: http://ec.europa.eu/internal_ market/social_business/index_en.htm [viewed: 02.07.2015].

The World Fact Book. The Population at Retirement Age Dependency Ratio. (2014). [Online] Available: https://www. cia.gov/library/publications/resources/the-world-factbook/ [viewed: 03.07.2015]. 


\section{VISUOMENÉS SENËJMO PROBLEMOS IR JU巳 SPRENDIMO B ÜDA I L A T V I J O JE, L IET UVOJE IR L E N K I J O J E}

Gunta Grinberga-Zalite, Evija Liepa, Vilma Atkociuniene, Joanna hernik Latvijos žemès ūkio universitetas (Latvija), Latvijos verslo kolegija (Latvija),

Aleksandro Stulginskio universitetas (Lietuva), Vakarų Pomeranijos technologijos universitetas (Lenkija)

\section{Santrauka}

Europos Sajungos duomenų tyrimai rodo augančią gyventojų senėjimo tendenciją valstybėse narèse. Tyrimo tikslai - išanalizuoti gyventojų socialinę struktūrą Latvijoje, Lietuvoje ir Lenkijoje, palyginti jas su ES 27 šalių narių vidutinemis gyventojų socialinès struktūros kitimo tendencijomis ir pateikti rekomendacijas politikos kūrejjams, kaip reikètų tobulinti socialinę politiką. Analizuojant teorinius visuomenès senejjimo ir gerovės aspektus taikytas monografinis tyrimo metodas, analizuojant antrinius duomenis remiantis Eurostato ataskaitomis, Eurobarometro apklausomis ir nacionalinių institucijų duomenų bazių duomenimis taikytas statistinių duomenų analizès metodas.

Latvijos, Lietuvos ir Lenkijos visuomenès senėjimo rodiklių analizė atskleidè, kad šių šaliu politikos kūrẻjai iki šiol daugiausia dẻmesio skiria visuomenèje nepopuliarioms priemonėms: arba didina mokesčius, arba ilgina pensinį amžių, tai sukelia piliečių nepasitenkinimą esama socialine politika, kuri neteikia jokių vilčių esamiems ir ateities pensininkams. Siekiant suvaldyti augantị visuomenès senèjimą reikètų daugiau investuoti į žmones ir jų paramos sistemas. Žmonès turètų lavinti saviorganizacinius gebejimus, gebèti priimti iššūkius ir juos transformuoti ị galimybes, suprasti savo poreikius ir prioritetus, jų siekti tenkinant poreikius. Straipsnio autoriai mano, kad nacionalinės institucijos, atsakingos už visuomenès gerovę, turètų skatinti novatoriškus sprendimus, neịprastų idèjų paieškas, gauti visapusišką paramą, įskaitant paramą, kurią numato politikos formuotojai, įtraukiant vietos subjektus. Reikia senyvo amžiaus gyventojus įtraukti į darbo rinką, ypač skatinti kurti sau darbo vietas, kad galètų išlaikyti darbo vietas, grįžti ị darbo vietas kaip laikini darbuotojai arba būtų ịgalinti dirbti kitokị darbą.

PAGRINDINIAI ŽODŽIAI: visuomenès senëjimas, išèjimas i pensija, gyvenimo kokybè, sèkmingas senëjimas, visuomenès socialinè struktūra.

JEL KLASIFIKACIJA: I31, I38 